\title{
Soro-Soke polemic \& the contemporary African female revolutionary trend: An Ngugian perspective
}

\author{
Terhemba Shijaํ \& Ifeoma Catherine Onwugbufor ${ }^{2}$ \\ ${ }^{1}$ Nasarawa State University, Keffi - Nigeria \\ Department of English. \\ ${ }^{2}$ Kwararafa University, Wukari-Nigeria \\ School of General Studies. \\ flyckeringhope@gmail.com
}

\begin{abstract}
A video revealing the assault of two men who were pulled out of a hotel and the execution of one of them by the Special Anti-Robbery Squad (SARS) became viral on October 4, 2020 spurring random protests across Nigeria. The protests which began as pockets of pickets snowballed into crowded rallies in the major cities comprising mainly, the youth shortly after the outbreak of a virtual protest with the \#EndSARS littering the social media, and eventually, the print media, and banners. Christened, Soro-Soke, these protests can be linked with a certain history - the actuality of the \#EndSARS protests against police brutality by Nigerians must have been predicted three decades ago by Ngugi wa Thiong'o whose late fictions prophesy palpable female intolerance of government ineptitude and a growing female revolutionary tendency
\end{abstract}


in Africa; a fervor which spread from Kenya through the entire continent. Ngugi's present affinity to strong female characters can be regarded as archetypal of his late fictions and nonfictions published from the 1980s. Matigari, Wizard of the Crow and Devil on the Cross will be interrogated as predictions of the \#EndSARS protests from an Ngugian perspective, while Ngugi's strongest nonfiction heroine, Me Katilili in his 2018 nonfiction, Wrestling with the Devil: A Prison Memoir will be synchronically analyzed alongside his imaginary heroines. Cultural Ecofeminism and Jungian Theory of archetypes interrogate the roles assigned by nature to Ngugi's most outstanding women in his late fictions, as part of a collective unconscious which is urgently typical of mankind.

Keywords: Aisha Yesufu, Soro-Soke, \#EndSARS, Feminist Coalition, Cultural Ecofeminism

\section{Introduction}

True for me Njoki, with a picture sent through the mail, and Waringa, with an image created on rationed toilet paper, have been more than a thousand trumpets silently breaking down the fortified walls of Kamiti Maximum Security Prison to assure me that I am not alone. (Ngugi, 2018, p. 40).

Significantly, a summation that Nigeria's \#EndSARS protests took life from Ngugi's imaginary woman today, will hold in the face of logical intellectual discourse on socialist issues as far as Nigeria and Africa are concerned. The pioneer \#EndSARS protests were launched by mostly women. One of such pioneer protests was organized by a female social media influencer, Rinu Oduala, who led a protest group to Lagos State government house; followed by Aisha Yesufu, a female Muslim who supported the youth protesters in Abuja with her presence but stood out to the front of the protest when the Nigeria police began to shoot at the protesters. She was the only person of all the protesters who refused to run.

The eruption of a chain of sporadic nationwide protests by the Nigerian youth (ages 18-45), referred to by Nigerian media as the 'Soro-Soke generation', marked the official national outcry against the dastardly acts of the SARS - an arm of the Nigeria Police Force charged with the 
responsibility of stamping out armed robbery, kidnapping and extortion. This comes in the wings of the fact that the protests which lasted many weeks were sustained primarily by women of different ages, professions and dispositions as they supplied food, cash, and other incentives which refueled the zest and dedication of the protesters for over ten days; as apparently, the men whose roles do not intercept with nature as with women, would not have been able to sustain the protests.

Categorically, this work attempts to mirror the growing defiance of the African woman whose revolutionary mindset topples patriarchy and tramples traditional theories which relegate women to the position of mere appendages. These females who sustained the \#EndSARS protests, cooking along the streets to ensure that protesters had no reason to leave, even when many of the females got raped by the same men while the protests went on, are champions of true revolution which comes to term with the fact that the African patriarch is unable to unshackle his society with its attendant manacle, dearth and debacle that only the woman can cleanse and rationalize.
Soro-Soke is an expression in Yoruba language which literarily means "speak loud", but figuratively denotes "stop sitting on the fence." This expression was deduced from the laughable defenses of many Nigerian politicians to undermine the protests which, in many ways represents Ngugi's post-Marxist reality driven by factual and pragmatic women. For the first time, feminists and other women totally disregard patriarchal narratives and collectively, rise in solidarity against the injustice and ruthlessness perpetrated under the watch of the current Nigerian leadership whose foremost mantra is CHANGE. These protests birthed the actuality predicted three decades ago through Ngugi's literary lenses in his late fictions, prophesying a growing female revolutionary tendency in Africa. It is at this intersection that the relevance of Ngugi's enigmatic ideology becomes indispensable in this study.

Nigeria, like Ngugi's home country, is bedeviled by a capitalist and inept leadership whose madcap governance and only ambition is wealth-grabbing at every opportunity, while the rich gets richer and the poor, poorer. The philosophy of theft is 
ingrained in the two systems represented by the settings under study, in the name of corruption, synonymous with capitalism thus:

... a system of unabashed
theft and robbery. Thus,
theft, robbery, and
corruption can never be
wrong under capitalism,
because they are inherent
in it ... Without a
systematic robbery of
peasants and workers, a
robbery protected and
sanctified by laws, law
courts, parliament,
religion, armed forces,
police, prisons, and
education, there is no
capitalism. (Ngugi, 2018,
p. 192).

It is impulsive to regard Ngugi a feminist writer as a result, yet his recent heroic choice cannot be dissociated from his sudden consciousness which is part of his prison experiences as he comes to term with his reality, and makes a firm decision, "Because women are the most exploited and oppressed of all working people. I would create a picture of a strong, determined woman with a will to resist and struggle against her present conditions. ..." (Ngugi, 2018, p. 15). It is against this background that this paper seeks to illuminate Ngugi's heroines who respond to the call to do the needful in the face of Kenya's struggle against colonialism and neocolonialism and the replica of the insidious role of women in the \#EndSARS protests in the different cities in Nigiera. Just like Ngugi's heroines leap from an imaginary status to reality, the Nigerian \#EndSARS protests unveiled women, chiefly Aisha Yesufu who like Wangari, stood before Nigeria's seat of power and speaking out against bad governance and police brutality:

We are citizens, we are not slaves. And we will continue to let them know that indeed, we are citizens and not slaves. Wherever we stand in this country, we stand as the citizens of the Federal Republic of Nigeria. We are not to be intimidated. You walk around here, you see police men with their guns, you see security agencies with their guns ... and we ask you, where are you when we are 
being kidnapped? Where are you when we are being killed? ... where were you when all sorts of things are happening to Nigerians. You come out with your guns ... you tell us you are men, you are women, but you are just whims. You are doing nothing. Nigerians are no safer on the streets. Nigerians are not safe in their houses, Nigerians are not safe anywhere. It is protesters that come out and you come out to intimidate... No Nigerian is more Nigerian than any Nigerian. Every one of us occupy the highest office in this land and that is the office of the citizen. The president occupies the highest political office so his office is less than our office. I am an employer of the president. I pay the president's salary, I pay the bills of his family and he must protect me whether he likes it or not. As the Commander-inChief, the president has failed. How many police were killed by terrorists in Borno? What have you guys done? I needed to see my commander ... all of you to go after Shekau and bring Shekau out. You are standing here with protesters ... Our soldiers are being killed all over ... it is high time we begin to do the tough job?, enough of the nonsense ... (Sahara Reporters).

\section{Literary criticism}

Two critical theories speak to the nucleus of this work - Cultural Ecofeminism and Archetypal Criticism.

\section{Cultural ecofeminism}

The foci of most feminist theories have always been directed at the subjugation of the female gender and the furtherance of her interests. Feminism to the African woman writer calculated resistance of this oppressive dictatorial agenda of patriarchy by conscious women, unlike 'western' feminism. At the backdrop of this, Nwagbara (2015) conceives of Feminism as a symbol of the exceptional consideration accorded women and issues relating to them everywhere in the world. It addresses the issues that women experience in patriarchal societies and 
illuminates their challenges to survive economically and politically.

Feminism and feminist writing began with Mary Wollstonecraft's $A$ Vindication of the Rights of Women in 1792. (Eze, 2016) Margaret Fuller's Women in the Nineteenth Century published in 1845 came afterwards, followed by many other writings prompting the emergence of the first wave of feminism. Considered as Western feminism initially, Feminism as a concept has dominated intellectual discourses in the Humanities for many centuries, and continuously evolves from the agitation for the ".... rights of women to vote, access to education and professions that were male-centered across Europe and America ..." (Ogun, 2018, p.88). Today, Feminism evolves continuously, and transcends these basic rights as Eze and Chibuko (2019) express unequivocally thus:

... the concept of Feminism is not just philosophical, it is a kind of Genderism that is based on the theory of individuality, recognition of the personhood of females and opportunity for self and societal development. It is a concept that celebrates women, a set of benefits and theoretical constructions about the nature of women oppression, and the part that this oppression plays within social realities... The restlessness of some Nigerian female playwrights today and their questioning of the status quo of their sex is a direct result of years of subjugation in the burden of patriarchy as portrayed in the works of some male playwrights. (pp. 312-313).

The philosophy which dictates the conceptualization of the different strands of Feminism finds relevance in Genderism, which denotes mischievous and antagonistic abrasive patriarchy; a cultural orientation and acceptance that a particular gender is superior to the other, and that gender is a binary phenomenon: man or woman. Basically, the general definition of genderism is "... the belief that a particular gender is superior to the other and has the right of control over the other gender." (Eze and Chibuko, p. 312) Unfortunately, drawing the line between gender and feminist strands can be a herculean task. It is for this reason that when a male child soldier kills only 
women, it is perceived differently from the feminist point where the female is perceived as the only victim, than when it is viewed from a gender point where he is identified as also, a victim. This writer concurs with the notion that "It is time we put the confrontational language behind us and understand that gender issues involve both genders, and diversity involves more than just gender." (McLeod, 2015).

Ecofeminism seeks to impose the consideration of the woman in her environment everywhere the woman exists. Interrogating this new perception justifies the presumption "... that women have a special and useful relationship to the physical world (bodies, nature) which can help end the unjustified dominations of both women and nature ..." (Warren, 2001) as projected by cultural ecofeminism which will be employed in this study. This is where the relevance of Ngugi's brand of feminist ideology becomes indispensable. Also, known as ecological feminism, Ecofeminism basically, interrogates the relationship between women and nature.
Deriving its name from three basic archetypes - culture, ecology and feminism, Cultural Ecofeminism also, called Spiritual Feminism rooted in essentialism, accentuates that cultural ecofeminism celebrates attributes that are exclusively feminine like intuition, emotions, care etc. Miles' further categorization identifies cultural ecofeminism as positing women to be intimate with nature due to their roles and biology as women. "... because of their gender roles (e.g. family nurturer and provider of food) and their biology (e.g. menstruation, pregnancy, and lactation) ... cultural ecofeminists believe that such associations allow women to be more sensitive to the sanctity and degradation of the environment."

Talking about gender roles, they are not completely determined by nature. Okolo and Ezegbe (2011) avow that "Gender role in every human society is determined by the type of socialization process of both sexes (male and female)." (p. 166). Citing Ikwumelu (1989), Okolo and Ezegbe insist that culture primarily, "... is learned consciously or incuriously through various learning processes and methods from generation to generation within a social 
group." (168) In other words, culture is acquired, and not innate; therefore, culture can be controlled. If this be the case, gender roles are assigned by the culture of the societies ingrained by many generations in the past. In Africa, culture assigns cooking of food to women, while in the European and other societies, men cook meals. Because change is constant, the culture of a society is as dynamic as other aspects; and thus, cultures continue to evolve.

Yet cultural ecofeminism maintain that because of women's outlined characteristics, they are closer to nature and actually, associated with the earth which is feminine and represents 'motherhood.' This implies that women, by extension, are also associated with a panoply of gods all linked with the earth in the traditional religion - hence, the reference to 'Mother Earth' by traditionalists in feminine terms. This may be the same reason women are associated with witches and mermaids more than the men. Also, the psychological makeup of women link them with nature. This is because women are naturally intuitive, emotional, spontaneous and sensitive; above their opposites. These are evident in the roles of Wariinga, Nyawira, Wangari, Guthera and of course, Me Katilili and the \#EndSARS heroines, whose affinity to nature including ecology in their countries; relating to voodoo, wilderness, etc. propel them to resent injustice and intimidation.

The spiritual characteristic of ecofeminism cannot be better be described as Mallory attempts in her 2018 work (2010, p.50), What's in a Name? In Defense of Ecofeminism as cited by Power (2016), "Nowhere is ecofeminism more fraught and fractured than over the question of spirituality." (p.36).

\section{Jungian theory of archetypes}

Archetypal criticism which is driven by the Jungian theory of archetypes as developed by the Swiss psychiatrist, Carl Gustav Jung in his theory of the human psyche, comes handy in the interpretation of this study. Archetypes are usually symbols prevalent in literature. Jungian archetypes are primarily applied to psychology and psychological patterns; but recently applied to arts, literature and music; and even advertising. (Toolshero "Psychology"). The word archetype, according to Golden is derived from an old Greek word 'archein' 
which means original, and 'typos' which also, means type, pattern or model. Archetypes are clearly defined as "...unconscious, universal idea patterns ... frequently used in mythology, saga, fairy tales and folktales around the world."

Jungian theory deals with archetypes which denote a pattern or imagery drawn from the collective experiences of the past and present in humans. According to Jung, there are archetypes in the unconscious memory of human beings retained from birth. Most archetypes including heroism, have existed from the origin of humanity, and these reside in the memory and are stimulated by circumstances. In this sense, this study explores what Nnolim notes as the 'darker recesses of the human psyche' even as Guthera, Mekatilili, Yesufu, Nyawira, Wangari and Wariinga seek to redeem the hopeless situations closing in on Kenya, Ilmorog, Nigeria, Aburiria and Matigari's unnamed country.

Although there exist over two hundred archetypes, Jung establishes the cogency of five kinds of archetypes: self, shadow, anima, animus and persona. Self-reveals the authentic personality of a human which can be improved. Shadow refers to the murky part of the human brain which craves to satisfy immediate needs. Mr. Hispaniora Greenway Ghitahy, the Rich Old Man from Ngorika and John Boy Jnr. represents what Jung calls the shadow.

Anima refers to the feminine aspect of the human psyche which is not gender specific. Animus is the male aspect of the human and like the Anima, is not gender specific. Finally, the Persona refers to the personality which the human exposes to the world. This is the good impression shown to other humans and is therefore, regarded as a social mask because this is most times, the opposite of what actually is.

It is acceptable to posit that themes are derived from archetypes; therefore, themes and archetypes are one and the same. While the mother depicts the protective female who always loves and understands, the hero is the champion who always solves a problem even at the expense of his life or position or substance; while the wise old man always presents with good counsel, and the trickster is always untrustworthy and a snitch; and the maiden always a beautiful and elegant woman; the fairy mother 
comes in at the last minute with fantasies of desires etc. (Toolshero "Psychology").

Arguably, Ryan (2011) in his studies, accentuates that an "Archetype literally means "first print" and refers to those images in the human mind that have been present since the dawn of time. From Jung's point of view, they are the building bricks of consciousness that are repeated in the literature, art, and architecture of different cultures all over the world." (p. 174)

Interrogating Ngugi's late fictions and nonfictions, it is identifiable that they are mostly inundated with myths, symbols and models drawn from different backgrounds and periods of time. Works which contain mythological elements adopt themes and symbols that are universal revealed in themes, character and characterization, imagery, and symbols; and these determine the unfolding of the plot of the work of literature. Because such works draw from universal archetypes, readers can easily relate with them because they are inundated with themes and other elements that are universal, therefore, easily graspable. Adoh (2014), in his detailed background of the mythological criticism, affirms that it attempts to define:

... and explore in succinct terms the concept of myth and mythic symbols. This approach is rigorous and wide in its application, unlike other literary approaches. Archetypes or archetypal symbols are an important aspect of the mythological approach. These symbols are not universally interpreted but analysed from a specific culture's point of view, for example, death, creation, the celestial bodies, predestination are identified as common archetypal symbols and themes; however, they can only be understood when placed within the context of a people's existence. The mythic approach is not only concerned with myths in their entirety, but with the 'whys' behind these myths. 
Although Ngugi's writing style remains unconventional especially in the African literary domain, this work attempts to illustrate the tangibility of Ngugi's imaginary female revolutions which otherwise, may have been conceived as larger-than-life many years ago, which play out during the \#EndSARS protests where women like Aisha Yesufu, DJ Switch, Damilola Odufuwa, Omoni Oboli, Tonto Dike, Odunayo Eweniyi, and other prominent females comprising of artists, activists, lawyers, etc., revolted against bad governance and police brutality in Nigeria in different capacities. Furthermore, this work hopes to erupt the consciousness of the African ruling elite who become worse in governance than their colonial predecessors, of the impending and unrestrained female insurrection lurking in the dark spaces of their subconscious.

\section{The feminist coalition: Conceptualization}

The Feminist Coalition can be regarded as a parallel correlation with Ngugi's Movement for the Voice of the People, in Wizard of the Crow. Although, GutheraMatigari association and Wangari-Muturu association had no umbrella name, their basic objective was to frustrate the evils of their governments, which was one of the objectives of the Female Coalition in Nigeria. Many Nigerian women formed organizations and communities whose primary objectives are centered on women, girls and children. This, many of them achieve through crowdfunding and donations with which they offered financial, moral, legal and emotional support to women and girl children. The idea is to be in the position to defend women and girls by fighting for their rights and assure their economic freedom. One of such communities is the Wine and Whine organization formed by Damilola Odufuwa; assisted by Odunayo Eweniyi, the Chief Operating Officer of PiggyVest and a renowned tech entrepreneur, to help women to operate a professional network. This is borne out of their passion for the female gender. When the opportunity came calling, Odufuwa formed the Feminist Coalition in July 2020. (Desmond, 2020). The major outreach of the Feminist Coalition was the \#ENDSARS protest which became their first project and a success too.

\section{Ngugi's women and \#EndSARS women protesters}

The \#EndSARS protests in many ways represent Ngugi's post-Marxist reality driven by factual and pragmatic women. The \#EndSARS protest in Nigeria which was called by no one in particular and had 
no leader was mainly run by Nigerian women. (Desmond, 2020). Against the backdrop of a feminist examination of women's participation during the \#EndSARS protest, this work attempts to affirm the rife possibility that Ngugi's late fictions sautéed in incredible female-led insurrections are prophetic, and are perfectly lived out in the \#EndSARS protest in the Nigerian terrain.

For the first time in recent times, African women; despite the malfeasance of their indigenous government, rose in solidarity with the men against the injustice perpetrated under the watch of the leaders. This the women achieved with a voice that totally disregarded patriarchal narratives. The heroic characterization of Ngugi's female characters will form the basis of this analysis which attempts a correlation between Ngugi's female revolutionary concept and the \#EndSARS protests in Nigeria. Simply put, these Nigerian females between three months and sixty-five years of age from all walks of life as demonstrated in many pictures which litter the social media, converged to throw their unalloyed and unprecedented support behind the patriarchal society which may not have gone half way to register a recognizable angst, were the victims of police brutality and is a female majority. At the backdrop of this, is the unprecedented avowal of Cloete (1998) thus;

Ngugi's rejection of the new African elitist rulers who practise and even revel in their abuse of power and their exploitation of the proletariat - in particular of females - as especially ... Devil on the Cross (1982) so forcefully demonstrate, is an essential part of his increasing urge to use literature as a means of political and social protest in post-independence Kenya." (p. 35).

Drawing intellectual inspiration from Ngugi's late fictions, the sustenance of the \#EndSARS protest by the Feminist Coalition can be placed in the midst of remarkable narratives in Ngugi's imaginative world. The facilitation of the protest by Wangari, Muturi and the leader of the Ilmorog University Students' Association (ILUSA) against the 
competition planned by the Organization for Modern Theft and Robbery at the Cave in Ilmorog was quickly garnered. As this organization, predominantly males, gather to select seven experts in modern theft and robbery $(1982,76,202)$ in the presence of the members of the International Organization of Thieves and Robbers from Sweden, Germany, England, France, Italy, America and Japan; (p. 78), their mindset becomes revealed in their mantra, "Let's not be fooled by socialist cant. To banish theft and robbery from a country is to stifle progress" (1982, p. 79).

Wariinga's lone revolution stirs a pandemonium in the home of The Rich Old Man of Ngorika, the father of Wariinga's fiancé, Gatuiria and her daughter; a man who was Wariinga's abuser once upon a time, (Ngugi, 1982, pp. 249-254) dispersing the guests who are present to receive her as a new bride. Many of these guests are members of the Association of Modern Theft and Robbery. The defiance of Wangari and Muturi suffused Wariinga with the courage and chutzpah to embark on her revolution - recognizing her driving force: "... suddenly remembering Wangari and Muturi and the student leader - the people who had roused her from mental slavery - she felt an anger she had not felt ..." (p. 254).

The significant gathering of the inauguration of the March to Heaven project in Aburiria by the Ruler and his ministers in Wizard of the Crow is typical of the ineptitude of Nigerian politicians who embark on senseless projects and whose initial insensitivity to the demands of the protesters, baptized the \#EndSARS protest with the new name 'soro-soke'. In the face of a dysfunctional government, who carefully ignored the outcry of Nigerians against the crimes perpetrated by the SARS officers for close to a decade. The \#EndSARS protests provide an opportunity for the Nigerian youth to put forward overarching petitions bordering on good governance, accountability, and probity. At this point, the Nigerian youth like the Movement for the Voice of the People led by Grace Nyawira (Ngugi, 2006, p. 22) in the Free Republic of Aburiria, readily disrupts unwholesome assemblies of Nigerian politicians which does not uphold public interest; or a flagrant showoff of impunity, skullduggery or preposterousness.

Similarly, the frustration of government's plans to incarcerate Matigari after 
Guthera rescues him from detention by devious means (Ngugi, 1986, pp. 65-66) and the reaction of the government to the \#EndSARS protests at the Lekki toll gate are one and the same; intricately woven. Many months after the \#EndSARS peaceful protests ended, the hashtag continues to trend especially outside the country, much as Matigari gained popularity after his first incarceration as a man of peace, "Who was Matigari ma Njiruungi; a person who could make prison walls open? From that night, Matigari's fame spread over all the country. He became a legend. He became a dream. Still the question remained: Who was Matigari ma Njiruungi?" (p. 66).

Ngugi's Devil on the Cross begins with an embattled Wariinga who had lost her job at Eldares after the back-to-back misfortunes that overwhelm her - refusal to 'open her legs' for Boss Kihara, lost her young boyfriend, got ejected from her house in the city of Nairobi and a suicide attempt - all narrated in brevity. This is to give way to the uncovering of the mindset of the competitors meant to inundate Ngugi's readers on the reasons behind the experiences, situations and mindsets of all the passengers in Mwaura's matatu which is the major aim of the writer.

Ngugi's apportioning of heroic characteristics to female characters in his late fictions and nonfictions, to a large extent, is a rare departure from the African literature typically described by 0jo-Ade (1983) as "... a male-created, maleoriented chauvinistic art. An honour-roll of our literary giants clearly proves the point: Ngugi wa Thiong'o, Senghor, Soyinka, Achebe, Mphahlele, and others." (p. 158).

It is without any doubt that in his late fictions and nonfictions, Ngugi begins to draw strength and fortitude from his female characters in his latest non-fiction, Wrestling with the Devil: A Prison Memoir, who are committed to fight the ugly consequences of the colonizers and 'the seventy years of their destructive alien presence' which is primarily characterized by the existence of Happy Valley, "... an actual area ... between Nairobi and Nakuru towns, but the name also described the lifestyle of a white landed idle class that killed bored by ... alcohol, other drugs, temporary marriages, divorce, wife swapping, murders, and suicide." (p. 44). 
These are in variance with the Gikuyu culture which Ngugi decries: "The more I dig up the sordid details of their Happy Valley lifestyle, the more it disturbed me ... Thus the knight commander of two saintly orders was the founding spirit of mass land robbery and of the not-too-saintly Happy Valley lifestyle." (2018, pp. 44 \& 46).

The rediscovery of women as champions of victory over evil, and the realignment of Ngugi's perception of women as agents of revolution is the thrust of this paper. Unlike his fictions during his early and mid-writing careers in which he presents men as embodiments of strength and doggedness, Ngugi establishes a new paradigm shift in his revolutionary ideology by announcing a roll call of heavy-duty women who tread the radical path that men feared to dare, keeping in mind all the time that "Despite independence, our status was still colonial ... a colonial affair in an independent Kenya. ... it is as if the phrase has followed me inside Kamiti Prison to mock me" (2018, pp. 41 \& 43). Citing Kathy Kessler (1994), Cloete (1998) rightly affirms that Ngugi "... positions women in the narrative and in the historical context in ways that foster the renovation of identity and tradition and redefine their roles in the development of a revolutionary consciousness." (p. 35).

\section{Me Katilili wa Menza: Ngugi's tangible imagination}

Me Katilili is the image of a Marxist woman which, unlike other female characters in the books under study, emanates not from Ngugi's imaginary creativity, but from a tangible and remarkable past during Kenya's resistance to British imperialist activity on the soil of Africa. Ngugi embarks on a daring mission to replicate Me Katilili's defiance in his female characters from Devil on the Cross to his 2020 epic, The Perfect Nine.

Me Katilili was a freedom fighter from the tribe of Girama in Eastern Kenya who lived towards the end of the nineteenth century. Although her given name was Mnyazi wa Menza, she became popularly known as Me Katilili (mother of Katilili) being a mother and her son's name was Katilili. Mnyazi's awareness to a revolution was triggered by the kidnap of Kithi her brother by Arab slave traders at a Kilifi market. (Google Arts and Culture) For her, that became the fulfillment of an age-long 
prophesy by the Girama diviner called Mepoho, who foresaw the coming of some strange persons. Mepoho's prophecy was fully authenticated by the arrival of the Imperial British East African Company (IBEA) who introduced hut-tax on the Girama people, plundering their resources including ousting them from their soil.

Me Katilili who was almost 70 at the time, resisted the British imperialist schemes using her people whom she drew using the Kifudu Giriama funeral dance. She made them to swear oaths to resist the foreign rule. Reputed to have supernatural powers from a Girama shrine, it was impossible, for the colonizers, to imagine how "... Kenyans find the nerve to reject foreign rule, domination, and oppression..." (2018, p. 72) In fact, the assistant district commissioner Arthur $M$ Champion on November 23, 1913 had written to his supervisor thus:

The witch Me Katilili and the witchdoctor, Wanji wa Mandoro about the end of June 1913, did stir up seditions amongst the natives of Gallana and Matafa in the district of Malindi and with this object, held a large gathering of men

determined to make a
common cause with
disaffected natives of Biria to
meat a spell or 'kiroho' for
the purpose of defeating a
successful government
administration ... (2018, p.
71).

This was followed by Champion's recommendation for the deportation and detainment of Me Katilili and Wanji. This was followed by their deportation to Gusiiland where they were eventually, starved to death. Me Katilili's altruistic disposition is constantly celebrated by Ngugi;

Now comes an even more remarkable feat by this woman. On January 14, 1914, Me Katilili and her fellow political prisoner escaped ... She was eventually caught on August 7, 1914 and imprisoned again. Me Katilili rejected the colonial culture of fear and the enslaved consciousness that it sought to instill in Kenyans. She remained proud, defiant, and unrepentant to the very end. (p. 72) 
Me Katilili whose outstanding valiance as a foremost Kenyan revolutionary is legendary, and carries a mythic denotation reflecting imaginatively almost a century after, is replicated in Wariinga as declared by Ngugi, "Wariinga will be the fictional reflection of the spirit of women's resistance and resilience in Kenyan history." (2018, p. 15).

Wangari, Nyawira, Wariinga and the enigma of Ngugi's female revolutionary ideology

Wariinga ngatha ya wira... Wariinga heroine of toil. .. there she walks haughtily carrying her freedom in her hands ... (Ngugi, 1981, p. 3).

Beginning with the identical characters of Guthera and Wariinga, these young women can be regarded to be in Ngugi's words, women who understand that "Modern problems are resolved with the aid of thighs ..." (p. 19), and this they live out every day of their lives. Wariinga's story which she recounts from pages 17 to 26 , are remarkable to the plot; especially the denouement and falling action of the work. Wariinga's angst against the Rich Old Man from Ngorika is summed up in
Kareendi's story, therefore, his eventual murder is a cancerous feeling which Wariinga did not hesitate to unleash when the opportunity called.

Muzigirwa (2010) accentuates that not only does Wariinga eventually succeed in going through school afterwards, to become an engineer, but also, she takes the responsibility as community spokeswoman and therefore, sharpens her forces against forces of evil, gathers means and skills, shows her concern for masses of workers, peasants and students' welfare above her personal pleasure and satisfaction ... and chooses a place among the peasants, workers, students and all those who pay by their brain, sweat and body to serve the kinds of the Old Rich man from Ngorika.

Ngugi recalls Kenya's historical heritage and the place of women, which not only informs his female affinity as revolutionary agents, but also, establishes the successes associated with them thus: ... Had I not seen glimpses of this type in real life among the women of Kamirithu Community and Cultural Center, with whom I worked to produce the play, Ngaahika Ndeenda? Isn't 
Kenyan history replete with this type of woman?

- Me Katilili wa Menza, Muraawa Ngiti, Mary Muthoni Nyanjiru, and the women soldiers of the Kenya Land and Freedom Army? (Ngugi, 2018, p. 15).

The Kenyan history and Ngugi's writings remain inseparable even as his thrust variegates. Embedded in the oral traditions of the Gikuyu people, Ngugi remains in touch with the geneses and subsequent close of the true ownership of nature's gift to Kenyans, not only to the colonizers, but also, to the Kenyan leaders who have consistently robbed the peasants and workers of their heritage, sadly. Ngugi's remarkable connection to this salient aspect of Kenyan history and the energy which he draws from this realization is thus, collectively expressed, "Waringa, by constantly making me conscious of my connection with history, and Njoki, by constantly making me aware that I am now in prison because of Kamirithu and its people, buoyed up my sagging spirits." (2018, pp. 40-41).

At the beginning of Devil on the Cross, Ngugi takes his time to describe
Wangira's economic state while she walked from one stall or hotel to another seeking a job, penniless and stranded, as a prelude to the introduction of the heroine, Wariinga and her significant meeting with Gatuiria. In fact, Wangari's joblessness earns her a detention in the police cell, and she secures a conditional release which boosts her interest to attend the Devil's Feast in fulfillment of her conditional release. This eventually, earns her the indefinite detention which succeeds the novel.

It is important to accelerate this study with the recognition of Wangari, an elderly jobless woman, whose bravado unleashes self-discovery that prods the heroine, Wariinga. Wangari's significance explains Ngugi's passion to develop the character of Waringa as the facilitator of the remarkable events that begins with the journey in Mwaura's matatu to the Devil's Feast at IImorog and beyond. This passion is not to be overtaken by any distraction as Ngugi declares (Ngugi, p. 7), "Tonight I don't want to think about guards and prisoners, colonial or neocolonial affairs. I am totally engrossed in Waringa, the fictional heroine of the 
novel I have been writing on toilet paper for the last ten months or so!"

\section{Ngugi's post-Marxist world and the signification of \#EndSARS}

The \#EndSARS protest demonstrates the capitulation of the economic might of women aligned with Ngugi's ideological paradigm which he validates. Burrowing into Guthera's economic inventiveness which gives freedom to the revolutionaries and ordinary citizens of Ngugi's unnamed country, Ngugi predicts the resourcefulness of Nigeria's Female Coalition and other well-meaning female citizens of Nigeria who financially funded the \#EndSARS protest (1987, p. 95); Wariinga's resourcefulness (1982, pp. 220-221); and also, the ingenuity of Grace Nyawira which does not only earn money for Comet Kamiti, but also, establishes his spiritual relevance in Eldares and indeed, Aburiria. (2007, pp. 367-369; 371 416, 460).

Nyawira seems to be the perfection of Ngugi's post-Marxist female character, whom he presents as a spiritual prophetess and an unapologetic moralist. A milder but more determined female revolutionary, Nyawira was turned on by one of her first major conversations with
(Comet) Kamiti revealing himself as a kindred spirit, "... I believe in humanity, divine, indivisible. We all need to look deeply in our hearts and the humanity in us will be revealed in all its glory. Then greed and the drive to humiliate others will come to a halt." (2006, p. 87) - words that eventually seduce her and lure her into Kamiti's arms, breathless. (p. 91).

The introduction of Ngugi's Devil on the Cross, leaves his readers in great suspense, their imagination running wild with an expectation of what his story will be about. Ngugi shocks his readers with the reality of the Organization for Modern Theft and Robbery and the membership of many of the competitors at the Devil's Feast, who made public their sources of wealth from the extortion of peasants. Their outrageous and outlandish strategies for robbery and theft; and also, their claims of cleverness are described by the author with the same grave satire and detachment with which the imprisonment of Muturi, Wangari and the students' leader is narrated. The introduction of Wangari gives credence to the revolutionist stance which propels Wariinga from the middle of the story till the end. 
programme which catches their intention

The significance of the Devil's Feast in the Cave which runs through the most part of the novel, cannot be overemphasized. The insidious revelation which the Devil's Feast divulges remains invaluable in the thorough comprehension of the reasons why Wariinga is exploited by Waigoka, why Boss Kihara attempts to exploit Wariinga sexually, why her young boyfriend jilts her and why these culminated in the several occasions she attempts to take her own life. It is therefore, appropriate to surmise that the Devil's feast is a vehicle through which Ngugi vividly illustrates the hopelessness of Kenyans, especially women, even in the hands of the government of her own people; and the futility of patriotism which only spells doom as it does in the country where the \#EndSARS is the last straw. The unwillingness of Kenya to be redeemed from herself is best revealed in the arrest of Wariinga by the police while she conforms with the conditions of bail earlier given to her.

Likewise, the introduction of the barmaids who serve drinks at the pub where Muriuki and Matigari sit to feed and have a drink, is remarkable. (p. 26). The subject of the also, portrays their mental obsession. It is the subject of interest of the barmaids that exalts Guthera's struggle with Matigari after he saves her from the Policemen and their dog. (Ngugi, 1987, pp. 29-32). Guthera's doggedness in resisting the policeman who seeks to lay her and her reasons, deifies the struggles of a typical subaltern woman. Like Kamiti in The Wizard of the Crow, Guthera explains the reason she won't mingle with a policeman, "... cops' money stinks of blood. I'd rather beg for a beer even from a total stranger - ..." (p. 28).

Wariinga belongs to the class of ladies regarded as 'loose', and this almost ruins her life as she takes most of the events in her life for granted. Using the allegorical narrative of Mahua Kareendi which she shares with Gatuiria, Wariinga summarizes the major factor that lures young ladies into promiscuity: unemployment, (Ngugi, p. 19) Extortion is a scourge which stifles many a woman in Kenya and hardly did such a woman survive without a huge prize. Heartless landlords enforce unlawful and brash ejections especially on women using intimidations and extortions, irrespective of their vulnerability. These women usually lose their self-confidence or their lives. Wariinga who decides to go back to her 
parents in IImorog after her ejection from 'the house in Ofafa Jericho, Nairobi' blames herself for her rejection as she:

... was convinced that her appearance was the root cause of all her problems. Whenever she looked at herself in the mirror she thought herself very ugly ... Insistent self-doubt and crushing self-pity formed the burden that Wariinga was carrying that Saturday as she walked through the Nairobi streets towards a bus stop to catch a matatu to take her to her parents' house in Ilmorog." (1982, pp. 11-12).

The case of Muriuki's mother is severe and irremediable. She wallows in misery and pays the ultimate price in the hands of a ruthless

landlord:

She used to rent a hut in the village but she could not afford to pay for it. The landlord told her to leave, but my mother asked him: Where will I go if I leave this hut? You can't throw me out into the wilderness like a wild animal. Money isn't more important than life! But the landlord answered: You have to go whether you like it or not. I will see to it myself that you leave ... It was midnight when I was woken up by the smell of smoke ... She was fast asleep. I tried to wake her up. I jumped out through the window, but my mother got stuck because the window was too small. Then the house burst into flames. (Ngugi, 1986, pp. 2526).

Matigari and Guthera discover their common heritage after he shares his story with her (pp. 38-39). From them on, Guthera puts on her revolutionary panoply which spurs most of her roles in the play. Without Guthera, Matigari would not have achieved much success both as a legend and a model revolutionary which Ngugi is determined to depict in Matigari. Both Guthera and Matigari become 'emergency' supernatural beings as they both in their unalloyed determination beat all scientific and logical possibilities beyond human comprehension. Ngugi transmits this heroism to his female child, Njoki born five months after his abduction whose picture posted to him at Kamiti Maximum Prisons carried a message from the peasants 
earnestly protesting, praying, groaning and wishing for his release. For Ngugi: Njoki is a message from the world. A message of hope. A message that, somewhere, outside these gray walls of death, people were waiting for me, thinking about me, perhaps even fighting for my release with whatever weapons they had. A protest, a hastily muttered prayer from the lips of a peasant, a groan, a sigh, wishes of helpless children: today such gestures and wishes may not be horses on which seekers of freedom may ride to liberty, but I embrace them as offerings of a much needed moral solidarity with us and with the issues for which we have been jailed. One day the organized power and united will of millions will transform these moral wishes into people's chariots of actual freedom from ruthless exploitation and naked oppression, but just now merely sensing them through Njoki's photograph is a daily source of joyful strength. (p. 17).

\section{\#EndSARS, literature and Ngugi's ideal: lessons to be learnt}

As early as 2009, many reports already reveal morbid information of extrajudicial killings of innocent Nigerians by the police. Many times, SARS officers became used by the rich and influential to carry out vendetta on their purported detractors. Innocent citizens were suddenly arrested at their places of business or work, denied legal consultation with their lawyers and executed secretly and buried in shallow mass graves. The \#EndSARS protests became the last opportunity for Nigerians to end the impunity of law enforcement agents. Unfortunately, the \#EndSARS protests did not last as long as planned, despite the systematic form which they took; "On 20, October, the Nigerian army violently repressed a peaceful protest at the Lekki toll gate, shooting at the protesters and killing at least 12 people. Since that day, the Nigerian authorities have tried to cover up the events of the Lekki toll gate shooting..." (Sotunde, 2020).

Ngugi's revolutions find relevance in the \#EndSARS protests. His characterization 
enables him to achieve the didactic aim which he sets out to do, in positioning the trio of Muturui, Wangari and the unnamed students' leaders as patriotic Kenyans like himself who choose a grassroot revolutionary approach that is unacceptable to the post-independent government of Kenya and earns their incarceration. By this, Ngugi creates in these three figures post-independence heroes in Ilmorog, just like he presents Kihika, as the pre-independent hero in Thabai which Nnolim (Eileen Julien, pp. 136-137) affirms thus, "It is the struggle against the British, the Emergency and Mau Mau that create for Kihika the occasion to realize his ideals for both himself and his people." In other words, Ngugi consciously recollects the heroic landmarks established by women in the history of Kenya, and thus determines that, "Wariinga will be the fictional reflection of the spirit of women's resistance and resilience in Kenyan History." (2018, p. 15).

Unarguably, excruciating economic condition debased femalehood in Kenya, and the women are given to promiscuity to survive. Yet the slight contrast is that Guthera is more defiant and poised. Both
Wariinga and Guthera learn eventually to stick to one man - that which is worthy of their fidelity and dedication. While Wariinga decides to settle in with Gatuiria, Guthera decides to be with Matigari, and these decisions they stick to till the end of both stories. Through their men, Guthera and Wariinga attempt to redeem hapless Kenyans from untold tragedy which Enewaridideke Ekanpou relates to societal error as he redefines the African tragedy beyond the factors of hamartia or hubris; but as a result of societal solecism. "Everybody waited for the words of Pere with curiosity, "I thank you all for coming; but let it be known that I shall satisfy the curiosity of my wife who had led me into this action and turn into a hill." (Ekanpou, 2007, p. 66).

Wariinga successfully eliminates The Rich Old Man from Ngorika who not only abused her sexually, but also, brought untold hardship to her when he got her pregnant and abandoned her. Wariinga states her mission categorically, when she realizes that her fiance's father is the man who exploited her in the past.

However, like Ngugi's revolutions, the EndSARS protesters demanded more than the dissolution of the SARS unit. 
While the nightmarish transgressions of the SARS unit were the spark for the outrage the protests have grown to encompass more than that single issue ... \#EndSARS protests have become a means to channel their (Nigerian youth) anger into creating a microcosm of a functional nation. (Effoduh, 2020).

In Ngugi's world as a Kenyan, the workers and peasants who were exploited, intimidated, imprisoned and subjugated include men and women who asserted their rights and demanded for better. Because the men were completely crushed during the Emergency with many of them in prison or concentration camps, the women manned up to their own defense. In Devil on the Cross, Ngugi's few female characters principally Jacinta Wariinga, a young girl from the Iciciri District, and an elderly, upright woman and peasant, Wariinga builds up a revolutionary spirit when the societal ill is at the verge of swallowing them, first, as females, and second, as humans living in postindependence Kenya. It is with the strongest of determination that these females rise up with arms and people to save themselves from exploitation and victimization that establishes the success and aesthetics associated with Ngugi's 1982 novel' a replica of the \#EndSARS protests.

Ngugi employs a female revolutionist to stamp out capitalism. Citing Brumley, Honore (2018) avers, "she chooses to reject the enslavement of capitalism, maintain her purity as her own woman, and kill the symbol of the capitalist beast. There is no doubt that Wariinga's feminization is complete." For the first time, Ngugi's commitment to project a female revolutionary is total. This he explains in these words:

Because women are the most exploited and oppressed of all working people. I would create a picture of a strong, determined women with a will to resist and struggle against her present conditions. Had I not seen glimpses of this type in real life among the women of Kamirithu Community Education and Cultural Center, with whom I worked to produce the play, 
Ngaahika Ndeenda? Isn't Kenyan history replete with this type of woman - Me Katilili wa Menza? Muraawa Ngiti, Mary Muthoni Nyanjiru, and the women soldier of the Kenyan Land and Freedom Army? Waringa will be the fictional reflection of the spirit of women's resistance and resilience in Kenyan History. (p. 15).

Using rugged heroines, Ngugi demonstrates that females can also, be sensitive to social issues championed decisively by them. Women become alternative models through which Ngugi sustains the revolutionary tendencies in his work, even while he tones down his Marxist approach. It may be illogical to accept Wariinga's revolution as a result of two experiences with The Rich Old Man from Ngorika, whose colonial name is Hispaniora Greenway Ghitahy and Boss Kihara who gave him a job after the two experiences narrated by Kareendi. For "She (Jacinta Wariinga) finds Nairobi, soulless and corrupt. For Wariinga, all her problems started with the Rich Old Man's adventure." (Honore, 2018).

Using the character of Kareendi, who is actually Wariinga, she reveals the vileness of sex exploitation of women in Kenya using two denigrating experiences which frustrate her while searching for a job in Nairobi in the second chapter. While at the second office she had entered, "She finds there another Mr. Boss. The smiles are the same, the questions are the same, the rendez-vous is the same - and the target is still Kareendi's thighs." (p. 19). As a matter of fact, the anecdote of Kareendi becomes the archetype of a female in Kenya in particular, and Africa in general. In combating the class discrimination, many women resort to changing their natural lifestyle and physical features in order to remain relevant. The pressures associated with Wariinga's existence inflicted on her by the Kenyan aristocrats - Boss Kihara and the Rich Old Man from Ngorika, imbues in her a complex that erodes her self-confidence:

Wariinga was convinced that her appearance was the root cause of her problems. Whenever she looked at herself in the mirror, she thought herself very ugly. What she hated most was her blackness, so she would disfigure her body with skinlightening creams like Ambi and Snowfire, forgetting the 
saying: That which is born black will never be white. Now her body was covered with light and dark spots like the guinea fowl. Her hair was splitting, and it had browned to the colour of moleskin because it has been straightened with red-hot iron comb ... (Ngugi, p. 11).

Wariinga's presence in Mwaura's matatu and listening to all the conversations opened her eyes to the sullen economic and social incapacitation which the Kenyan aristocrat places the hapless citizens of the country. The speech of Mwireri wa Mukiraai during the Devil's feast at the cave, is significant as it surmises the essence of Kenyan capitalism. His remarkable logic is later to unfold during the Devil's Feast at the Cave. (1982, p. 79).

Wariinga's revolution actually begins with herself - her mindset, her personality and her career. Thus, the narrator exclaims, "Here is Wariinga! ... This Wariinga is not the one we met two years ago. This Wariinga is not the one who used to think that there was nothing she could do except type for others ..." (p. 216). Attending to one of the research objectives, the deification of women as better revolutionists authenticates the fantastical entanglements with the major character, Jacinta Wariinga whose otherworldly encounter with the Devil from the beginning of the novel ceases after the Devil's Feast which marks a turning point in her life. With her association with Guthuira and her selfdiscovery which puts her back on her career path, Wariinga becomes a confident woman who decides to walk over her impediments while she searches for an end to the societal ills that attempts to suppress and frustrate her and many others. Wariinga, at the end of the novel, successful attempts to cleanse the society beginning with the restoration of her confidence for the task ahead of her, thus: Today's Wariinga has decided that she'll never again allow herself to be a mere flower, whose purpose is to decorate the doors and windows and tables of other people's lives, waiting to be thrown on to the rubbish heap the moment the splendor of her body withers. The Wariinga of today has decided to be selfreliant all the time, to plunge into the middle of the arena 
of life's struggles in order to discover her real strength and to realize her true humanity. (p. 216).

Next, she realizes her dream career by proceeding to the Polytechnic where she qualifies as a mechanical engineer who specializes in motor vehicles and other internal combustion engines, although the Kenyan society "... loves to denigrate intelligence and intellectual capacity of our women by saying that the only job, "... a woman can do are to cook, to make beds, and to spread their legs in the market of love." (p. 218). Yet Wariinga, in challenging the mindset of Kenyan men, reminisces loudly, "Why have people forgotten how Kenyan women used to make guns during the Mau Mau war against the British? Can't people recall the different tasks carried out by women in the villages once the men had been sent to detention camps?" (Ngugi, p. 245). While she pursues her education in engineering, she also, attends "... judo and karate classes at the Kenyan Martial Arts Club in the Ngara area. Wariinga had resolved that she should be able to defend herself and stand on her own in every way." (p. 219).
Although she runs into financial difficulties while in school, she refuses to accept help from her boyfriend, Guthuira or any other person, as self-reliance is for her, a hallmark of her new self. During her first year in school, she would rather take up side jobs like typing research papers and dissertations for other students, or worked in the hairdressing salon. (p. 219) By her second year, she had learned enough to offer her services to the Mwihotori Kiwanja Garage where she proves her worth, 'daring to storm a man's citadel and received better pay and nicknamed, 'Wariinga, daughter of the Iregi rebels!' (pp. 220-222).

By taking on a career which is maledominated, she gears up for the confrontations which her new mindset would thrive on. Her first male victim is a man who brings his vehicle for repair and touches her breasts and buttocks. (1982, p. 221) She moves to destroy the unrepentant Rich Old Man from Ngorika who on meeting her as his daughter-inlaw to-be attempts, to destroy the new life she had begun to lead, (p. 251) Wariingai like Soyinka's lyaloja in Death and the King's Horsemen according to Okolocha (2015) is "... the true hero because she 
remained steadfast in her responsibility to society and that her character calls attention to the existence of powerful female figures ..." (p. 96) within her society.

Although Ngugi's heroine, Wariinga did not lead a strike, she champions a cause which is much more decisive by taking up the responsibility to deliver the society from the wiles of thieves and robbers by outright extermination. In a decrepit postindependence Kenya where the rich manipulate the public institutions including the police, the presidency, the courts of law etc., which no longer dispense justice or truth, Wariinga takes the laws into her own hands and heeds the call to duty. She takes her revenge and "... walked on, without once looking back." (p. 254).

What is most significant is that women's revolution against the collaborators of the devil according to Honore (2018), is "... against neo-colonialism as a political system and capitalism as the economic system ruling the particular fictional society called modern Kenya". Women protagonists use methods and strategies to free themselves from victimization.
Through their conquest, the aim is to save all Kenyan people, especially the ones who belong to the lower class. This is also the, the objective of the female participants in the \#EndSARS protests.

Experiencing the colonialist Emergency from childhood, eventually succeeded by the insensitivity of the postcolonialist and neocolonialist periods, Ngugi has remained in touch with the social injustices met to Kenyans which directly affects his own family. He therefore, finds his works as a vehicle to reveal the weight of his angst against the Kenyan leading aristocrats. All he needs is the social experience to reveal the Kenyan leaders who permit the rot in the system; a confirmation of the unapologetic view of Gbilekaa (2012, p. 29) that social experience is to the writer what water is to the fish as it provides the source materials which the writer's imagination reflects on in order to produce pieces of artistic writing including a hero figure to complement.

Like God who after creating the world looks back and said that his creation is good, Ngugi after he created the character of Wariinga looks back after thirty-six 
years in his deification of his heroines and recounts in his latest memoir, " ...Waringa ... Njoki ... my symbol of hope and freedom ... I am the first political prisoner to hear these words. I shout the news across the walls. "Free ... We are now free." I am no longer K677. I have regained my name. Ngugi wa Thiong'o. (pp. 237, 239, 240).

\section{Conclusion}

Ngugi's revolutions as portrayed in his late fictions are powered by women from wide spectrum of age and professional inclinations. While Wangari and Me Katilili are elderly women, Guthera, Nyawira, Vinjinia and Wariinga are young women whose experiences and foresight go beyond their ages and professional backgrounds. Likewise, the \#EndSARS protests also, had the participation of many Nigerian women of different strata and age. In fact, Folu Adeboye the wife of one of Nigeria's most revered Pastors, and General Overseer of The Redeemed Church of God donated generously to the sustenance of the protesters in the Alausa area of Lagos, when the \#EndSARS protests was in its $12^{\text {th }}$ day. She had donated, "... 200 cartons of bottled water, 1000 bags of sachet water and 27 bags of freshly made puff puff." (Ashekun, 2020)
Aisha Yesufu in her thirties had spoken outstandingly and fiercely when she unequivocally declared the plight of Nigerians, "The SARS police said to us that they would waste us and nothing will happen to us ..." (Sahara Reporters).

Remarkably, the religious condemned the brutality of Nigeria police, condemning the execution of the protesters and the failure of the police to "... arrest the weapon-bearing hoodlums who were attacking the well-organized and nonviolent \#EndSARS protesters." (Ajala, 2020).

The liberation which Ngugi's imaginary and real women seek is for the entire Kenyan population under the yoke of exploitation and abuses. As far as the aim is concerned, although Wangari's move to arrest the thieves and robbers of the Kenyan economy and the forerunners of capitalism in Kenya failed woefully, she made a statement with her action and intent. These influence Wariinga, thus beginning a more decisive and continuous and prolonged cleansing that is obviously suggested at the end of the novel, DOC.

Further than this, is Wariinga's resolve for which she sacrifices her long sought-for 
love - a rosy affair that sprouts between her and Gatuira, in order to crucify the debauchery of Waigota by murdering him, despite the fact that he is the father of the man he loves. Ngugi weaves a story which from the onset sets the target of the novel in the first place, outside which nothing else matters, "The Devil who would lead us into the blindness of the heart and into the deafness of the mind should be crucified, and care should be taken that his acolytes do not lift him down from the cross to pursue the task of building Hell of the people on Earth ..." (p. 1).

The women in Ngugi's literary life wear a significant robe that endear them to Ngugi in ways he is unable to appropriately describe; yet he is able to put it so perceptively thus:

Wariinga and Njoki also, keeps reminding me that my imprisonment without trial is not a personal affair. It's part of the wider history of attempts to bring up the Kenyan people in a reactionary culture of silence and fear, and of the Kenyan people's fierce struggle against them to create a people's revolutionary culture of outspoken courage and heroism. (p. 41).

Ngugi's women remain thorough in their revolutionist outlook at the point they make up their minds to join. Like Habila's girls, Ngugi's heroines are "... ordinary girls who had taken a leap of faith ... Like most things in life, it all came down to chance, opportunity, and desperation. There was no single explanation." (p. 85) Otherwise, Guthera would not have been able to keep Matigari alive for that long, neither would Wariinga have been able to take her revenge on the Rich Old Man from Ngorika to save his future victims. The significance of the \#EndSARS heroines' protests are summed up in Aisha Yesufu's words, a replica earlier spoken by Wangari in Ilmorog:

The \#EndSARS protest has been peaceful until government decided to bring in thugs ...these thugs went rogue and attacked protesters and now, attacking properties of Nigerians. And it's sad that our government tends to do things without thinking of the repercussions. And when the \#EndSARS protesters 
were able to apprehend some (government-sponsored thugs) and hand them over to the police, the police refused to arrest them. So it's the way politicians and those in government have constantly done their things ... For me, it remains that young people found their voices and are speaking up. It shows Nigerian youth are standing, are resolute and are determined that something is going to come out of it. In the end, power belongs to the people. ... (Nasiru, 2020). 


\section{Reference}

Adoh, C. "Myth and Worldview in Wole Soyinka's Death and The King's Horseman and Ola Rotimi's The Gods are not to Blame." Slideshare. Feb 26, 2014 Retrieved from https://www.slideshare.net/tboneyfan12/myth-and-worldview-in-wole-soyinkasdeath-and-the-kings-horseman-and-ola-rotimis-the-gods-are-not-to-blame

Ajala, Samuel A. "\#EndSARS: Adeboye, Bakare, Suleman condemn Killing of Protesters." Premium Times. Oct 21, 2020. Retrieved from https://www.premiumtimesng.com/news/morenews/433181-endsars-adeboye-bakare-suleman-condemn-killing-of-protesters.html.

Ashekun, F. (2020, October 18). \#EndSARS: Adeboye's wife donates 3 trucks of food, water to alausa protesters. Newsmakers. Retrieved from https://www.newsmakerslive.org/endsars-adeboyes-wife-donates-3-trucks-of-foodwater-to-alausa-protesters/

Cloete, Nettie. "Women and transformation: A recurrent theme in Head and Ngugi." Uterator, 19(2), Aug 1998, pp.31-45.

Desmond, Vincent. "How Women Powered Nigeria's \#ENDSARS Movement." Elle. Nov 18, 2020. Retrieved from https://www.elle.com/culture/career-politics/a34699000/endsarsnigeria-feminist-coalition/.

Ezeh, P-J. (2016). A survey of socio-anthropological thoughts for African studies, (3rd Edition). Enugu, Nigeria: ABIC Books and Equip Limited.

Effoduh, Jake 0. "Why Nigeria's \#EndSARS Movement is More than a Call to End Police Brutality. World Economic Forum. Dec 21, 2020. Retrieved from https://www.weforum.org/agenda/2020/12/nigeria-endsars-police-brutality-protest/

Eze, Godstime, and Chibuko Daniel. "Genderism in Nigerian Drama: The Example of Wole Soyinka's The Lion and the Jewel and Child Internationale." Ikenga International Journal of Institute of African Studies, UNN, vol. 19, no 1, 2019, pp. 312-321. Retrieved from http://www.ikengajournal.com.ng/admin/img/paper/CompleteIKENGA-VOL.-19-No.1.pdf

Ekanpou, Enewardideke. The Road to Ken Saro-Wiwa. Cotigo Media, 2007.

Gbilekaa, S. (Ed.). "Nigerian Literature and Social Experience: The Zaki Biam Experience." Difficult dialogues in development. A festschrift: Charity Ashimen Angya. Kraft Book, 2012. 
Golden, Carl. "The 12 common archetypes." Soulcraft. Retrieved from www.soulcraft.co/essays/the_12_common_archetypes.html

.National Museums of Kenya. "Mekatilili Wa Menza: The Story of the Girama Wonder Woman." Google Arts \& Culture. Retrieved from https://artsandculture.google.com/story/mekatilili-wa-menza-the-story-of-thegirama-wonder-woman/uOJiyBBzmBOAKg

Habila, Helon. The Chibok Girls. Parresia, 2016.

Honore, Ngoie Mwenze. "Women's Fight in Ngugi Wa Thiong'o's Devil on the Cross: A Structural Analysis. Green Journal of Language and Literature Research, vol. 4, no. 1, April 2018, pp. 1-11.

Julien, E. "Heroism in A Grain of Wheat." In E. D. Jones (Ed.), African Literature Today. Heinemann, 1983.

McLeod, Andrew. "Feminism or Genderism: Which is the Right Way?" Feb 2015. Retrieved from https://cornerstonecapinc.com/feminism-or-genderism-which-is-the-right-way/.

Miles, Kathyrn. "Ecofeminism Sociology and Environmentalism." Britannica. Retrieved from https://www.britannica.com/topic/ecofeminism.

Muzigirwa, B. "Devil on the Cross: Ngugi's Marxist Invitation." Grin. 2010. Retrieved from https://www.grin.com/document/200641.

Nasiru, Jemilat. "'He never shows empathy' - Aisha Yesufu blasts Buhari over silence on Lekki shooting." The Cable. October 23, 2020. Retrieved from https://www.thecable.ng/henever-shows-empathy-aisha-yesufu-blasts-buhari-over-silence-on-lekki-shooting/.

Ngugi, wa Thiong'o. Matigari. Digitalized by RevSocialist, 1986.

Devil on the Cross. Heinemann, 1982.

Wrestling with the Devil: A Prison Memoir. Vintage, 2018.

In the House of the Interpreter. Vintage, 2013.

Wizard of the Crow. First Anchor, 2006.

Nwagbara, Chinyere. Soyinka's Feminist Aesthetics. Rasmed, 2015.

Shija. Onwugbufor. $\quad$ https://doi.org/10.53836/ijia/2021/22/2/003 
Ogun, Abhulimen. "Beauty and Feminism in Richard Masagbor's Labyrinths of a Beauty." Hyuku Journal of Interdisciplinary Research, vol. 2, no. 1, Jan 2018, pp. 87-95.

Eldred Durosimi Jones, editor, African Literature Today. Heinemann, 1983.

Ojo-Ade, F. (1983). Female writers, male critics. In E. D. Jones (Ed.), African Literature Today. (pp. 158-179). London, UK: Heinemann Educational Books.

Okolo, A. N., and Ezegbe, B. N. "Gender Role in African Indigenous Knowledge: Implication for Preservation of African Cultural Heritage." Ikenga International Journal of Institute of African Studies, UNN, vol. 12, no 1, Sep 2011, pp. 161-174. Retrieved from http://www.ikengajournal.com.ng/admin/img/paper/lkenga\%20vol\%2012\%20no\%201 .pdf

Okolocha, Oby H. "Heroism as Social Responsibility: Decoding the Mystique of 'Iyaloja' and the Power of Duty in Wole Soyinka's Death and the King's Horseman. Journal of the Literary Society of Nigeria (JLSN), Jun 2015, pp. 96-115.

Power, Chelsea. "Multispecies ecofeminism: Ecofeminist Flourishing of the Twenty-First century." Being a Thesis submitted to the Department of Sociology, University of Victoria in Partial Fulfilment of the Requirements for the degree of Master of Arts. 2016.

Ryan, M. "Fearful Symmetries: William Blake, Northrop Frye, and Archetypal Criticism." ESC, vol. 37, no. 2, Jun 2011, pp.173-183.

Sahara Reporters. "\#RevolutionNow: Buhari Has Failed - Aisha Yesufu's Speech at \#October1stProtest That Had Security Agents Lowering the Barrel of their Guns." October 3, 2020. Retrieved from https://youtu.be/NOS3YsiTQfO

Sotunde, Afolabi. "\#EndSARS Movement: From Twitter to Nigerian Streets." Amnesty International. Retrieved from https://www.amnesty.org/en/latest/campaigns/2021/02/nigeria-end-impunity-forpolice-violence-by-sars-endsars/

Warren, K. J. (n.d.). Feminist theory: Ecofeminist and cultural feminist. In International Encyclopedia of the Social \& Behavioral Sciences, 2001. Science Direct. Retrieved from https://www/sciencedirect.com/topics/social-sciences/ecofeminism.

Toolshero. Psychology. Retrieved from www.toolshero.com/psychology/theories-ofpersonality/jungian-archetypes/. 